Article

\title{
Material Efficiency of Building Construction
}

\author{
Antti Ruuska * and Tarja Häkkinen \\ VTT Technical Research Centre of Finland, Tekniikantie 4, 02044 VTT Finland; \\ E-Mail: tarja.hakkinen@vtt.fi \\ * Author to whom correspondence should be addressed; E-Mail: antti.ruuska@vtt.fi; \\ Tel.: +358-20-722-6733; Fax: +358-20-722-7007.
}

Received: 21 March 2014; in revised form: 4 May 2014 / Accepted: 16 June 2014 /

Published: 1 July 2014

\begin{abstract}
Better construction and use of buildings in the European Union would influence $42 \%$ of final energy consumption, about $35 \%$ of our greenhouse gas emissions and more than $50 \%$ of all extracted materials. It could also help to save up to $30 \%$ of water consumption. This paper outlines and draws conclusions about different aspects of the material efficiency of buildings and assesses the significance of different building materials on the material efficiency. The research uses an extensive literature study and a case-study in order to assess: should the depletion of materials be ignored in the environmental or sustainability assessment of buildings, are the related effects on land use, energy use and/or harmful emissions significant, should related indicators (such as GHGs) be used to indicate the material efficiency of buildings, and what is the significance of scarce materials, compared to the use of other building materials. This research suggests that the material efficiency should focus on the significant global impacts of material efficiency; not on the individual factors of it. At present global warming and greenhouse gas emissions are among the biggest global problems on which material efficiency has a direct impact on. Therefore, this paper suggests that greenhouse gas emissions could be used as an indicator for material efficiency in building.
\end{abstract}

Keywords: material efficiency; resource efficiency; energy efficiency; building; construction; land-use; life-cycle; case-study; greenhouse gas; abiotic resource depletion 


\section{Introduction}

Resource efficiency means efficient use of energy, natural resources, and materials, in order to create products and services with lesser resources and environmental impacts. It is based on life-cycle thinking and comprises of energy efficiency and material efficiency. Whereas the energy efficiency considers sparing use of energy, and ratio of energy use and production, material efficiency is about sparing use of natural material resources, effective management of side-streams, reduction of waste, and recycling [1].

Natural resources underpin the functioning of the European and global economies and the quality of life. These resources include raw materials, such as fuels, minerals and metals, as well as food, soil, water, air, biomass, and ecosystems [2]. A roadmap to a resource-efficient Europe [3] highlights the buildings sector as one of the three key sectors for improvements. Better construction and use of buildings in the European Union would influence $42 \%$ of final energy consumption, about $35 \%$ of our greenhouse gas emissions and more than $50 \%$ of all extracted materials. It could also help to save up to $30 \%$ of water consumption.

The importance of material efficiency and the need to improve it can be studied from several perspectives. Limited availability or scarcity of materials may lead to threats to the economy, and the production processes of materials can have significant environmental impacts. The extraction of raw materials and the production of materials may also be energy and/or labor intensive and very costly, and the extraction of materials may lead to land use changes and related impacts.

This article presents an overview of the different aspects of resource and material efficiency in building construction. The paper also presents the results of a case study and analyses the significance of building materials in terms of material scarcity.

\subsection{Classification of Resources (and Aspects of Scarcity)}

Natural resources can be divided into renewable and non-renewable resources. Non-renewable resources are those that can only be harvested once. These are often referred to as stocks (e.g., iron ore) or resources that form extremely slowly (e.g., crude oil) [4]. Azapagic [5] divides the minerals industry into energy minerals (e.g., coal, oil), metallic minerals (e.g., iron, copper and zinc), construction minerals (e.g., natural stone, aggregates, sand, gravel, gypsum), and industrial minerals (e.g., borates, calcium carbonates, kaolin, plastic clays, talc).

A reserve is defined as that part of the reserve base that could be economically extracted or produced at the time of determination (in accordance with the terminology used by the European Commission [6]). The reserves of the most common building materials (aggregates, clay, lime and stone, gypsum, and quartz) are either large or very large [4]. However, buildings also consume materials whose reserves are more limited, for example, coal, oil, and metallic minerals.

The usability of resources depends specifically on the economy and the available technology. Resources that have previously been uneconomical to extract may become usable because of rising values and improved extraction technologies. Political situations and the effects of extraction on the landscape and environment may also affect the usability of resources. Scarcity always has a time dimension: it can be interpreted as a change in availability over time [7]. Steen [8] claims that many 
life cycle impact assessment (LCIA) approaches mix scarcity with issues such as difficulty of extraction. This can be viewed as double counting, as the effects thereof, such as high energy demand, are accounted for in other categories. Metals in use can also be seen as a global inventory of available metals. Virgin metal is added when necessary to this inventory [9]. Future backup technologies will probably require significantly less energy and other resources than the extraction of virgin metal.

Meadows et al. [10] identify that the increasing cost of resources is becoming a major problem for societies. As resources become scarcer, this may influence the quality of life in some parts of society. This, in turn, may have negative impacts on human health as a specific area of protection [11]. It may therefore be important not to separate the environmental and economic aspects. Yellyshetty et al. [12] argue that resource depletion needs to be considered in LCAs from the perspective of time, environmental and economic aspects of mineral extraction, and future consequences of decreased availability of mineral resources for a region. Steen [8] highlights three issues that should be considered when drawing conclusions about the inclusion of resource depletion in LCAs: (1) the time perspective when evaluating impacts on abiotic resources; (2) the separation of environmental and economic aspects; and (3) whether the consequences of decreased availability should form part of the LCI or the LCIA. The socio-economic value of mineral extraction can be significant in some regions, and changes in the extraction industry can have important social consequences [13]. Söderholm and Tilton argue that economic depletion will occur long before physical depletion [14].

Another way of looking at the issue of mineral resource scarcity is the surplus cost method, which assumes that future increases in mining volume will lead to increasing production costs per metal or mineral extracted. This is defined as the marginal cost increase (MCI). When the MCI is multiplied by future resource demand, the future costs to society can be determined $[15,16]$.

\subsection{Indicators for Resource Efficiency and Material Efficiency in the Building Industry}

Resource efficiency can be defined with a number of indicators. Each indicator has a specific definition, which contains only certain aspects of the issue. Resource efficiency may be defined, for example, in terms of land area that an economy requires [17], human impacts on natural processes [18], impacts on land use [19], amount of material use [20] or related environmental impacts [21], ratio of GDP to material use [3], or national monetary input-output tables expanded with environmental information [22].

When moving from the level of economies to the level of technologies or products, other life-cycle related indicators are more common. The indicators are typically not correlated, so a wide range of environmental indicators are needed [23]. For example, life cycle assessment (LCA) methodology assesses the harmful impacts of buildings in terms of global warming, ozone depletion, acidification of soil and water, eutrophication, photochemical ozone creation, and depletion of abiotic resources (elements and fossil fuels) [24,25].

The impacts from resource use, often referred to as, resource depletion, is a prominent impact category in LCA [26]. LCA methodology addresses abiotic, or non-living, resources in terms of their availability for present and future generations. The depletion of such resources can be studied from the perspective of amounts of deposits, extraction rates, future ore extractions, or exergy consumption [27]. 
The use of natural raw materials in building can be decreased by using lightweight structures, minimizing loss, improving durability and service life, using secondary materials and improving appropriate flexibility $[28,29]$. Improved space efficiency also contributes to better material efficiency when assessing it in terms of functional units (a building that fulfils the required performance).

The following equation shows how these different aspects of material efficiency relate to the wider concept of resource efficiency. Equation (1) defines the total impacts associated with the production and processing of a specific material as (adopted from [30]):

$$
\mathrm{I}=\mathrm{D} \times \mathrm{M} \times \mathrm{Y} \times \mathrm{E}
$$

In Equation (1), the impacts (I) are due to the demand (D) for products containing material, the average mass of material per product $(\mathrm{M})$, the yield ratio of supplied material versus material in the final product $(\mathrm{Y})$, and the average emissions per unit of material (E). The impacts of material efficiency extend to all the factors, D, M, Y, and E. In the context of buildings, the demand for new buildings is influenced by their durability, service life and flexibility. The use of lightweight structures impacts the average mass per product, and the yield ratio is affected by material losses during processes. Finally, the use of secondary materials impacts - in addition to the use of natural material resources - the average emissions, as reuse and recycling are typically significantly less energy intensive than primary production [30].

Instead of viewing material efficiency through the multiple viewpoints presented above, this research focuses on their total impacts. This research outlines the related impacts as follows: (1) depletion of natural raw materials; (2) impacts of material-related harmful emissions; (3) impacts due to material-related land use; and (4) life cycle costs due to the use of materials. The following sections discuss the importance of these different impacts, on the basis of literature.

\section{Aim and Scope}

The objectives of the research were as follows:

- to outline and draw conclusions about different aspects of the material efficiency of buildings;

- to assess the significance of different building materials on the material efficiency of buildings.

The study was founded on the premise that the importance of material efficiency is based on one or more of the following impacts:

- the depletion of raw materials and its long-term socio-economic impacts;

- land use change due to the extraction of raw materials and its environmental impacts, and impacts on the landscape and future recreational use;

- the use of energy in production processes of materials and depletion of non-renewable energy;

- harmful emissions from production processes of materials and their local and/or global environmental impacts;

- material cost impacts due to the limited availability of raw materials or a higher need for energy and/or labor in the different phases of production processes. 
The different aspects of the material efficiency of buildings were outlined and analyzed with the help of a literature study. The importance of the different groups of building materials and the significance of building materials compared with the use of energy resources was studied with the help of a case study. The Abiotic Depletion Potential (ADP) was calculated in terms of ADP elements and ADP fossil, and the significance of different building materials was assessed.

With regard to the building sector, the research questions of interest are as follows: (1) "As the global availability of the main building materials is very good, should the depletion of materials be ignored in the environmental or sustainability assessment of buildings?"; (2) "Although the availability is good, are the related effects on land use, energy use and/or harmful emissions significant and should related indicators (such as GHGs) be used to indicate the material efficiency of buildings?"; (3) "Although the availability of the main building materials is very good, what proportion of buildings use scarce materials and what is the significance of these compared with the use of other materials in buildings?".

\section{Literature Review}

This section presents the literature review, which answers the research questions of this paper on a general level. It also points out the gaps in literature and gives reasoning for the selected case-study approach, which is presented later in this paper.

The literature review examined the impacts of material efficiency on: (1) depletion of natural raw materials; (2) impacts of material-related harmful emissions; (3) impacts due to material-related land use; and (4) life cycle costs due to the use of materials. It aimed to identify and fill potential gaps in the current knowledge and point out needs for more detailed studies.

\subsection{Scarcity and Availability of Abiotic Building Materials}

Material efficiency is a way to reduce the demand of abiotic building materials. Whereas the importance of material scarcity is growing in general, the issue is not as clear for building materials. Common building materials, such as metals and ceramics, are derived from ores. Some of the minerals are approaching their production peaks and some have already passed their peak [31]. There is also a continuous decrease in ore grade at which some materials are being mined [32]. The inevitability of peaking of oil is generally acknowledged, although, it is still under debate, whether or not the peak has already passed [33]. Oil is needed, for example, for production of polymer-based building materials.

The building industry uses large amounts of materials, equating to approximately $50 \%$ of European resource extraction [3], but the most common building materials are also common in nature. Aggregates, for example, are the key component of many building elements but are generally not a scarce resource [34]. However, due to their heavy and bulky nature, aggregates need to be sourced close to their markets. Viable sources may be constrained at regional and local level [35], for example in rapidly growing developing countries [36], if their viable local supply is not strategically planned [6]. Relating to these problems, approaches which account for local resources have been proposed in literature [37].

The buildings also require metallic minerals for the production of, for example, concrete reinforcements and structural steel in the building frames, roofs, façades, windows and doors of the 
building envelope and pipes, ducts and wirings of building systems. Despite of dependence on the import of metallic minerals in some countries [34] these resources are not considered scarce, as their global availability is good [6]. However, mining of these minerals may become critical in terms of social impacts that mining activities cause locally on land and ecosystems [38].

When buildings become more energy efficient and building systems more advanced and complex, the demand for scarcer resources may increase. Some of the components of advanced, energy-efficient building systems, such as wind turbine magnets, high-capacity batteries, energy-efficient lighting and photovoltaic cells require rare earths and critical natural resources in their production [39]. However, the exact selection and weighting of factors, which make a raw material critical or scarce, are still open research questions [40]. Raw materials may be considered critical, for instance, if they have national significance for economies and their current or future supply is at risk [39]. Other sources of criticality may rise from specific ecological, social, or political considerations [6].

\subsection{Greenhouse Gases}

The building sector is the single largest contributor to global greenhouse gas emissions. On the other hand, it also has a substantial emission saving potential. Material efficiency extends to all the underlying factors of resource efficiency, making it a significant contributor to resulting impacts from materials. Considering these viewpoints, material efficiency has a significant role in reducing the global GHG emissions from buildings.

The greenhouse gas emissions from buildings are related to the embodied energy of building materials and the emissions from operational energy use and the role of materials is becoming increasingly important. The research and policies have focused only on the operational energy use until recently [41-43]. This can be explained by the fact that, the role of embodied energy has been relatively low, at some $10 \%-20 \%[44,45]$, but development towards more energy efficient buildings increases the importance of materials. In low-energy buildings the role of materials can be as high as $50 \%$ [41] and ultimately, at zero-energy-level, all the energy-consumption, and related greenhouse gas emissions come from the embodied energy of building materials [42]. Due to this development, the embodied energy and related emissions cannot be omitted in life cycle assessments.

In addition to initial material consumption, the buildings also need materials for their lifetime renovations. The energy consumption of interior renovations over the lifetime of a building can account for some $20 \%$ to $30 \%$ of the initial embodied energy [46]. The need of this recurrent embodied energy can be almost halved, with the use of materials with longer service life [47].

When looking at the issue from the level of residential areas, also transport needs to be considered. Significant greenhouse gas savings can be achieved in all, embodied, operational and transport energy needs when planning residential areas [48]. From sector-level, the most important factors affecting the greenhouse gas emissions are housing size, style and location [49].

Another viewpoint to the issue is the temporal perspective of emissions from building. The initial GHG emissions emitted over a short period of time in the construction phase may compromise the greenhouse gas mitigation goals in short and medium term [50]. Therefore, the greenhouse gas emission targets cannot be achieved with energy-efficient new buildings alone. 
Ruuska and Häkkinen [28] assess the total greenhouse gas emissions of a multi-storey residential building in Finland with the help of a parametric study. The results show for a concrete building case that material-related emission account for some $40 \%$ of 50 -year lifetime total GHG-emissions for a passive-level building in Southern Finland. Furthermore, if soil stabilization of a building site is included in the figures, the role of materials rises to over $50 \%$ of lifetime totals.

\subsection{Land Use}

Construction causes irreversible land changes. Use of land means consumption of resources, in terms of changing the potential end-use and the consumption of soil materials. Buildings use land directly by occupying the land under their footprints and through their embodied land use, relating to their raw material and energy use throughout the building's value chain. An impact because of land use occurs when the land properties are modified (transformation) and also when the current man-made properties are maintained (occupation) [51]. Changes in land use can have wide-ranging environmental consequences, including biodiversity loss, changes in emissions of gases affecting climate change, changes in hydrology, and soil degradation [52].

Buildings and other construction assets cause soil sealing as land remains below constructions. Artificial sealing is generally extensive and permanent [53]. When vegetated soils are replaced with impermeable surfaces, it results in the increase of overland flow, reduction of infiltration and bypass of natural storage [54].

Although the global availability of the main building materials is good, the consideration of land use may affect the importance of material efficiency with regard to buildings. However, an LCA-based case study analysis [55] indicates that when only non-renewable material resources are considered, the land occupied by buildings is more important that the land use due to the extraction of raw materials used for buildings. However, when wood is used as a building material, the land use (in terms of occupied land area) required for the production of building materials becomes more significant than the land occupancy of the building itself.

The extraction of aggregate materials also affects the landscape and the natural geological and biological conditions. In addition to this, in Finland, the extraction of gravel affects the quality of the groundwater because the extraction increases the variety in the quality and pollution risk of the groundwater [56]. In addition to the impacts on groundwater and surface water, the production of aggregates causes local impacts, such as vibration, and noise and dust emissions.

\subsection{Cost and Productivity}

Material efficiency has an important effect on construction cost efficiency. The positive impacts on cost and productivity can be seen as a natural driver towards material efficiency in the building industry.

The importance of materials in relation to the investment costs of construction varies. The approximate magnitude has been estimated at $15 \%-40 \%$ of the investment cost (including the cost of design, interfaces, labor costs, site overheads, taxes and the contractor's profits) [29]. Minimizing the loss of materials has a direct impact on the investment costs. On the other hand, better and appropriate flexibility in the design of spaces can also have a significant impact on the life cycle costs, especially in the context of retail and office buildings. 
Goodrum et al. [57] studied the relationship between changes in material technology and productivity in construction. The results show that changes in material technology correlate with improvements in both labor and partial factor productivity (physical output per material cost + equipment cost + labor cost). The authors found that the relationship between changes in material technology and construction productivity was weaker for labor productivity than for partial factor productivity. The strongest relationship between changes in material technology and labor productivity was also found among changes in the unit weight of materials followed by modularity, curability, and installation.

\subsection{Existing Standards and Regulation}

The current European regulation, as well as the work done for the development of assessment standards, reflects the stated policy targets to consider and improve the material efficiency and the overall resource efficiency of societies. However, unlike energy performance, which is defined by European Directives [58,59], material efficiency is not tightly controlled or regulated. Also, contrary to the energy efficiency of building and renovation [60,61], there are no fiscal instruments or incentives in place for improvements in material efficiency of buildings.

In Europe, the Construction Product Regulation [62] gives basic requirements for construction products. Construction works as a whole and in their separate parts must be fit for their intended use, throughout the life cycle of the works and fill the basic requirements. Sustainable use of resources is included in the requirements, and the CPR states that construction works must be designed, built and demolished in such a way that the use of natural resources is sustainable. Especially the following is highlighted: (1) re-use or recyclability of the construction works, their materials and parts after demolition; (2) durability of the construction works; and (3) use of environmentally compatible raw and secondary materials in the construction works. Even though the Construction Product Regulation emphasizes the importance of material efficiency, it does not give normative rules for it, or dictate mandatory information about material efficiency.

Assessments of resource depletion and comparisons of buildings and building products are supported by international and European standards. The current standardization and guidelines suggest using two separate impact categories for resource depletion: ADP elements for all non-renewable abiotic materials and ADP fossil fuels for all fossil resources [24,25,63]. Previously, both these items were assessed in terms of antimony equivalents [64]. However, as the two contribute towards the decrease of different resources, their ADP is characterized by different units [65]. The unit of measurement for the depletion of natural resources is the antimony equivalent ( $\mathrm{kg} \mathrm{Sb} \mathrm{eq})$ and for the depletion of natural fossil energy the resources, their net calorific value (MJ). Despite of its established status through the current standardization and guidelines, the calculation of ADP has some shortcomings. For example, the characterization factors for its calculation do not exist for many of the common building materials. The basic problem behind this is that such factors cannot be defined for many of the common building materials, such as gypsum, silica sand, construction sand, clays, limestone, and such, due to lack of data on material configurations, reserves, reserve bases, and ultimate reserves for these materials [65]. 
The status of ADP calculations in standardization and the identified shortcomings in the calculation method, give a basis for the case-study of this research. The literature study was unable to identify detailed ADP calculations, which would show the importance of different building materials. The case-study aims to create new knowledge on the importance of different building materials, in terms of their ADP. It also aims to compare the material-related ADP to the ADP from lifetime operational energy use. Finally, it aims to give more information on the significance of the use of different scarce materials in buildings.

\section{Quantifying the Abiotic Depletion Potential (ADP) of Buildings}

The case-study aims to add to the existing knowledge by showing the importance of different building materials, in terms of their abiotic resource depletion potential (ADP). It also studies the importance of building materials, in relation to operational energy use and the role of advanced building systems. Finally, the case-study offers new information on the current calculation method for ADP, together with its limitations. These issues were selected as the focus of the case-study, based on the gaps in the existing literature.

This section presents the case-study building, and explains the calculation method and main data sources used in the study. This case-study assesses the resource depletion of a case-building, by using impact categories of ADP elements and ADP fossil, recommended by current standardization and guidelines. The following subsections go through the calculation method, principles of the used life cycle assessment method, material quantities used in the assessment, calculation of energy consumption and, especially, calculation of ADP elements and ADP fossil.

\subsection{Calculation Method}

This research used life cycle assessment to determine the ADP of a case building. The calculation was carried out by using the bill of quantities (BOQ) of a real world building and assigning each of the materials with a specific characterization factor for their ADP (elements). For ADP fossil, the energy consumption associated with the materials of BOQ was completed with lifetime energy consumption information.

\subsubsection{Life Cycle Assessment}

Life cycle assessment means compiling and evaluating inputs, outputs and environmental impacts of a product system throughout its life cycle [66]. It is widely accepted as one of the best tools for environmental assessment of a variety of products and processes [67]. This research uses a process-based analysis, which is generally recognized as more accurate, but more labor, and time-intensive than, for example, input-output analysis $[68,69]$. The selected method and its limitations and benefits are examined in more detail in the 'discussion'-section. The life cycle assessment is limited to the abiotic depletion (ADP) of non-renewable raw materials and fossil fuels. The assessment does not aim to be exhaustive, but it aims to define the ADP of building materials with sufficient accuracy. The specific focus of this research is on the product stage, but also construction, use and end 
of life stages are assessed to cover the whole life cycle of the building, following the division of current standardization [24]. The assessment period of this research was 50 years.

\subsubsection{Material Quantities}

The material quantities required for the assessments of the product stage were based on the bill of quantities (BOQ) of a real-world case building, which is described in further detail later on. The BOQ was derived from the building's building information model (BIM), hence offering a high level of accuracy in material amounts. For calculation purposes, the materials of the BOQ were categorized under nine identified main material groups, namely: aluminium, concrete, copper, fossil materials, gravel, other mineral resources, steel, wood boards, and other wood-based products.

In addition to the quantities of the BOQ, the lifetime material consumption, including waste during construction stage and material requirements for use stage were also accounted for. The material loss was estimated to be $5 \%$ for all the building materials, for both construction and use phase material needs, based on literature [70]. The material needs of the use phase were assessed by estimating replacement and refurbishment needs over the lifetime of the building, for different building parts and components. The material needs of maintenance and repair were estimated to be insignificant and they were not accounted for in the assessment.

The following assumptions were made for the lifetime renovations. Firstly, the load-bearing structures were assumed to last for the whole lifetime of the building. Secondly, the roofing, building systems, windows, doors, glazing, and the surfaces of sanitary spaces were expected to be replaced (or refurbished) once over the 50-year assessment period. Thirdly, the surface finishes, fittings and furniture were expected to require replacement in every 10 years, thus, they were assumed to undergo four renewals over the assessment period.

\subsubsection{Energy Consumption}

The energy consumption of the product stage was taken into account by using life cycle inventories (LCI), which included energy consumption from raw material supply, transport and manufacturing from cradle-to-gate. Energy consumption of construction installation process and transportations were taken into account in the construction phase. For the use phase, the assessment included the energy consumption of replacement and refurbishment, transportation of materials and operational energy use of the building. The end of life phase included energy needed for deconstruction and transport of waste from site. The waste processing and disposal stages were excluded for this assessment. Data sources used for these calculation are shown in more detail in the next section.

\subsubsection{Calculation of ADP Elements}

The calculation of ADP elements had five steps. Firstly, total material needs over the lifecycle of the building were defined. This was done by combining the information from the original BOQ with the estimates on material losses during construction $(5 \%)$ and assumptions on replacements and refurbishments. Each of the materials was then categorized under one of the identified nine main material groups. 
The second step was to define the total abiotic material inputs for each of the main materials. This was done using the European ELCD database and its LCI data [71] for this purpose.

The third step was to derive the ADP characterization factors for each of the abiotic inputs. The characterization factors used are based on the CLM database's base reserve figures [72], as recommended in current guidelines [64].

Fourthly, after designating the ADP characterization factors for each of the abiotic inputs of the main materials, the average ADP factor for each main material was calculated.

Finally, when all the material amounts, and corresponding ADP characterization factors were defined, the ADP for each material was calculated. After this, the building-level ADP was calculated by adding together the ADPs of all the nine main materials. The results of calculations, together with references to the used data sources are presented in section "ADP Elements".

This research also considers the specific issue of soil stabilization, which may be needed in case of poor ground conditions on building site, as it has been previously found to be significant building factor impacting (GHG) emissions [28] and its main components have high embodied energy. The ADP Elements calculations follow the same methodology as described previously, the only difference being the main materials in stabilization are cement (CEMII) and quicklime $(\mathrm{CaO})$ with a mixing ratio of 1:1. In addition, ADP Fossil is assessed for the soil stabilizations. The assessment results for soil stabilization, along with the data sources, are presented in section "ADP of soil stabilization".

Another specific issue studied by this research is the ADP of advanced building systems of energy-efficient buildings, because such systems typically include rare earth elements and other critical materials [39]. The components selected for study are energy-efficient lighting and PV panels. The ADP Fossil of these is not calculated due to a lack of reliable data. The calculation results and data sources are shown in section "ADP of advanced building systems".

\subsubsection{Calculation of ADP Fossil}

The ADP fossil calculations followed a similar methodology to that of the ADP elements. For material-related ADP-fossil, the calculation comprised of three stages.

Firstly, the total material needs over the lifecycle of the building were based on the total masses calculated for ADP elements.

Secondly, the non-renewable energy inputs for each of the main materials were derived from the ELCD database [71] to give a characterization factor for ADP fossil for each of the main materials.

Thirdly, when all the material amounts, and corresponding ADP Fossil characterization factors were defined, the ADP for each material was calculated. After this, the building-level ADP was calculated by adding together the ADPs of all the nine main materials. The results of calculations, together with references to the used data sources are presented in section "ADP Fossil".

In addition to the direct, material-related energy consumption, fossil energy is also consumed in material transportation. The contribution of transportations to the ADP Fossil is calculated by assuming a $50 \mathrm{~km}$ transport with a semi-trailer combination to the building site for all the materials and the same $50 \mathrm{~km}$ distance for all the materials to cover their transport off the site with earth moving lorry at the end-of-life. The construction installation process, lifetime replacement and refurbishment activities, and deconstruction of the building at the end-of-life also consume fossil energy. These are 
assessed using values from previous research. The assessment results for transportations, and construction, lifetime renovations and demolition are shown in section, along with the used data sources “ADP Fossil of Material Transportation and Construction Work".

To complete the ADP Fossil calculations, lifetime operational energy use is also assessed. This is done by assessing the operational energy consumption over the lifetime of a building. This research divides the operational energy consumption into three items: space heating, hot water, and electricity. The calculations are based on standard energy consumption of buildings, in terms of end use of energy. The end use of energy is then converted into non-renewable primary energy, based on country-specific energy production profile. Furthermore, as energy production is constantly developing, future energy production scenarios are used to forecast the development of the use of non-renewable primary energy over the life cycle of 50 years. All of these calculations, together with the used calculation data, are presented in section "ADP of the operational energy use".

\subsection{Case Study Building}

All of the ADP calculations were made for a specific case building, which was located in Southern Finland, and represented a typical Finnish contemporary building. The building under study was a six storey residential building with a basement floor. The gross floor area of the building was $3060 \mathrm{~m}^{2}$ and the number of apartments was 28. The structures of the building were passive-level and the heating method was district heating. The load-bearing frame, consisting of internal and external walls, floor slabs and roof, were precast concrete structures. The bill of quantities, extracted from the building information model (BIM) of the case building was used as the basis of the calculations of this research. Material quantities of the case building are not shown here, as they are presented later in this paper, in the result tables for the ADP (Tables 1 and 2).

\section{Results}

The following subsections present the calculation results of the case-study, along with the references for the used data sources. The ADP elements and ADP fossil for the case building are shown in the first two subsections, followed by results for soil stabilization. After this, the impacts of advanced building systems are assessed, followed by the impacts of transports and construction work. The last result section shows the results for ADP from operational energy use and compares it to the material-related ADP results.

\subsection{ADP Elements of Building Materials}

This section shows the results for ADP Elements of building materials for the case building. The following table (Table 1) shows that the total need of building materials over a 50-year life cycle for the case building is $4960 \mathrm{t}$, or $1.62 \mathrm{t} / \mathrm{m}^{2}$. The total material need includes the initial material needs for construction of the building $(89 \%)$, recurrent material needs for replacements and refurbishments (6\%), and material losses $(5 \%)$. The table also shows that the production of the building materials for the case-building requires a total of $7320 \mathrm{t}$ of abiotic inputs, or $2.39 \mathrm{t} / \mathrm{m}^{2}$. According to the results, the 
building-level abiotic depletion potential, over the lifetime of the building, is $1.05 \mathrm{~kg}$ of Antimony equivalents, or $0.34 \mathrm{~g} / \mathrm{m}^{2}$.

In addition to these results, the following Table 1 also includes the ADP characterization factors used in the calculations for each of the main materials. It also shows the noteworthy information on abiotic inputs, which lack an ADP characterization factor, and are therefore not included in the calculation results.

\subsection{ADP Fossil of Building Materials}

This section shows the results for ADP Fossil of building materials for the case-building. The total material needs presented in the following table (Table 2) match those presented in the previous section. According to the results, the ADP Fossil of the case-building is 15,900 GJ of fossil energy inputs, or $5.2 \mathrm{GJ} / \mathrm{m}^{2}$.

\subsection{ADP of Soil Stabilization}

This section studies the effect of soil stabilization on the ADP elements and ADP fossil. The total material need for stabilization is $1420 \mathrm{t}$, including material losses (5\%). The following Table 3 shows that the ADP elements value of soil stabilization is $530 \mathrm{~g}$, or $0.17 \mathrm{~g} / \mathrm{m}^{2}$, and that the ADP Fossil is $3500 \mathrm{GJ}$, or $1.14 \mathrm{GJ} / \mathrm{m}^{2}$.

\subsection{ADP of Advanced Building Systems}

This section assesses the ADP elements of advanced building systems. The ADP Fossil is not assessed, due to lack of reliable data.

\subsubsection{Energy-Efficient Lighting}

This section shows the calculation results for ADP Elements of energy-efficient lighting. The selected lamp type is a standard T12-type fluorescent lamp with a rare earth triphosphor coating, with a coating thickness of $5 \mathrm{mg} / \mathrm{cm}^{2}$ [73] and a total of 7 grams of phosphorous coating. In addition to this, the lamp has low-pressure mercury vapor, with an estimated amount of $25 \mathrm{mg}$ per lamp [74]. Assuming a service life of 10 years for the lamps, four replacements are required over the 50-year life cycle. The case building has a total of 355 lamps.

The following Table 4 shows that ADP Elements for energy-efficient lighting is $0.12 \mathrm{~kg}$ of Antimony equivalents, or $0.38 \mathrm{~g} / \mathrm{m}^{2}$. 
Table 1. Total mass of materials, abiotic material inputs per ton material ton, abiotic material inputs with no abiotic depletion (ADP) characterization factor, average ADP characterization factor of abiotic inputs, total ADP of materials and data source for material inputs.

\begin{tabular}{|c|c|c|c|c|c|c|c|}
\hline Material & $\begin{array}{c}\text { Total mass of } \\
\text { materials (t) }\end{array}$ & $\begin{array}{l}\text { Abiotic material inputs } \\
\text { per material ton }(t / t)\end{array}$ & $\begin{array}{c}\text { Total abiotic } \\
\text { material inputs (t) }\end{array}$ & $\begin{array}{c}\text { Abiotic material inputs } \\
\text { with no } \text { ADP }_{\mathrm{CF}}(\%)\end{array}$ & $\begin{array}{l}\text { ADP }_{A V G} \text { of abiotic } \\
\text { inputs (t Sb eq /t) }\end{array}$ & $\begin{array}{c}\text { Total ADP of } \\
\text { materials (kg Sb eq) }\end{array}$ & $\begin{array}{l}\text { Data source for } \\
\text { material inputs }\end{array}$ \\
\hline Aluminium & 29 & 4.8 & 142 & $87.2 \%$ & $3.22 \times 10^{-6}$ & 0.46 & [75] \\
\hline Concrete & 3549 & 1.4 & 5016 & $99.9 \%$ & $8.28 \times 10^{-9}$ & 0.04 & [76] \\
\hline Copper & 4 & 6.0 & 26 & $99.2 \%$ & $1.90 \times 10^{-5}$ & 0.49 & [77] \\
\hline Fossil materials & 90 & 2.8 & 256 & $99.9 \%$ & $7.40 \times 10^{-10}$ & 0.00 & [78] \\
\hline Gravel & 629 & 1.9 & 1202 & $100.0 \%$ & - & - & [79] \\
\hline Other minerals & 337 & 0.8 & 254 & $100.0 \%$ & $2.83 \times 10^{-10}$ & 0.00 & [80] \\
\hline Steel & 83 & 3.5 & 291 & $91.6 \%$ & $1.86 \times 10^{-7}$ & 0.05 & [81] \\
\hline Wood & 42 & 0.1 & 5 & $99.7 \%$ & $4.79 \times 10^{-9}$ & 0.00 & [82] \\
\hline Wood boards & 200 & 0.6 & 129 & $99.7 \%$ & $4.84 \times 10^{-9}$ & 0.00 & [83] \\
\hline Total & 4960 & - & 7319 & $99.3 \%$ & - & 1.05 & - \\
\hline
\end{tabular}

Table 2. Total mass of materials, fossil energy inputs per ton material ton, total ADP Fossil of materials and data source for material inputs.

\begin{tabular}{ccccc}
\hline Material & $\begin{array}{c}\text { Total mass of } \\
\text { materials (t) }\end{array}$ & $\begin{array}{c}\text { Fossil energy inputs } \\
\text { per material ton (GJ/t) }\end{array}$ & $\begin{array}{c}\text { Total ADP of } \\
\text { materials (GJ) }\end{array}$ & $\begin{array}{c}\text { Data source for } \\
\text { material inputs }\end{array}$ \\
\hline Aluminium & 29 & 37.0 & 1088 & {$[75]$} \\
Concrete & 3549 & 0.8 & 2720 & {$[76]$} \\
Copper & 4 & 17.5 & 75 & {$[77]$} \\
Fossil materials & 90 & 85.6 & 7696 & {$[78]$} \\
Gravel & 629 & 0.1 & 38 & {$[79]$} \\
Other minerals & 337 & 3.7 & 1259 & {$[80]$} \\
Steel & 83 & 15.7 & 1297 & {$[81]$} \\
Wood & 42 & 0.6 & 27 & {$[82]$} \\
Wood boards & 200 & 8.7 & 1728 & {$[83]$} \\
Total & 4960 & - & 15,900 & - \\
\hline
\end{tabular}


Table 3. Total mass of materials, fossil energy inputs per ton material ton, total ADP Fossil of materials, abiotic material inputs per ton material ton, abiotic material inputs with no ADP characterization factor, average ADP characterization factor of abiotic inputs, total ADP of materials and data source for material inputs for soil stabilization of case-building.

\begin{tabular}{|c|c|c|c|c|c|c|c|c|c|}
\hline Material & $\begin{array}{l}\text { Total mass of } \\
\text { materials (t) }\end{array}$ & $\begin{array}{c}\text { Fossil energy } \\
\text { inputs per material } \\
\text { ton }(G J / t)\end{array}$ & $\begin{array}{c}\text { Total ADP } \\
\text { Fossil of } \\
\text { materials (GJ) }\end{array}$ & $\begin{array}{l}\text { Abiotic material } \\
\text { inputs per } \\
\text { material ton }(t / t)\end{array}$ & $\begin{array}{c}\text { Total abiotic } \\
\text { material } \\
\text { inputs (t) } \\
\end{array}$ & $\begin{array}{c}\text { Abiotic material } \\
\text { inputs with no } \\
\operatorname{ADP}_{\mathrm{CF}}(\%)\end{array}$ & $\begin{array}{c}\mathrm{ADP}_{\mathrm{AVG}} \\
\text { of abiotic inputs } \\
(\mathrm{kg} \mathrm{Sb} \mathrm{eq} / \mathrm{t})\end{array}$ & $\begin{array}{c}\text { Total ADP } \\
\text { of materials } \\
(\mathrm{kg} \mathrm{Sb} \mathrm{eq)}\end{array}$ & $\begin{array}{c}\text { Data source } \\
\text { for material } \\
\text { inputs } \\
\end{array}$ \\
\hline CEMII & 709 & 3.6 & 2558 & 1.7 & 1199 & $99.6 \%$ & 0.00045 & 0.53 & [84] \\
\hline $\mathrm{CaO}$ & 709 & 5.4 & 3820 & 3.2 & 2303 & $100.0 \%$ & - & - & [85] \\
\hline Total & 1420 & 9 & 6380 & 5 & 3500 & $99.8 \%$ & - & 0.53 & - \\
\hline
\end{tabular}

Table 4. Total weight of selected materials, ADP characterization factors for materials and total ADP for lighting, based on a single lamp type over a 50-year life-cycle with four replacements.

\begin{tabular}{ccccc}
\hline Material & $\begin{array}{c}\text { Total weight of } \\
\text { materials }(\mathbf{k g})\end{array}$ & $\begin{array}{c}\mathbf{A D P}_{\mathbf{C F}} \\
\mathbf{k g}(\mathbf{S b} \text { eq) } / \mathbf{k g}\end{array}$ & $\begin{array}{c}\text { Total ADP } \\
\mathbf{k g} \text { (Sb eq) }\end{array}$ & $\begin{array}{c}\text { Data source for } \\
\text { characterization factors }\end{array}$ \\
\hline Mercury & 0.04 & 2.62 & 0.12 & {$[72]$} \\
Rare earth elements & 12.71 & 0.0006 & 0.007 & {$[86]$} \\
Total & 12.76 & - & 0.12 & - \\
\hline
\end{tabular}




\subsubsection{Solar Panels}

This section looks at the photovoltaic panels of solar panels and shows their contribution to the depletion of abiotic resources, in terms of ADP Elements. The selected panels are of two types: c-Si (Crystalline Silicone) and CIS/CIGS (Copper Indium Selenide/Copper Indium Gallium (di) Selenide). The main material is glass, which forms approximately $74 \%$ to $84 \%$ of the total mass. The remainder is aluminium (10\% to $12 \%$ of the total mass) and other metals ( $4 \%$ to $16 \%$ of the totals), as summarized in a report to the European Commission [87]. Assuming that the lifetime of the panels is 15 years, the panels will need to be renewed three times over the lifetime.

The results in Table 5 show that the ADP for solar panels may vary from 180 to 174,000 $\mathrm{kg}$ of Antimony equivalents, or $60 \mathrm{~g} / \mathrm{m}^{2}$ to $60 \mathrm{~kg} / \mathrm{m}^{2}$.

Table 5. Total area of solar panels, ADP characterization factors per square meter of panel, and total ADP for solar panels over a 50-year life-cycle with three replacements.

\begin{tabular}{cccc}
\hline Panel type & Total area of solar panels $\left(\mathbf{m}^{\mathbf{2}}\right)$ & $\mathbf{A D P}_{\mathbf{C F}} \mathbf{S b}$ eq $\left.\mathbf{( k g} / \mathbf{m}^{\mathbf{2}}\right)$ & Total ADP Sb eq (kg) \\
\hline c-Si & 370 & 0.2 & 180 \\
CIS/CIGS & 370 & 157 & 174,380 \\
\hline
\end{tabular}

\subsection{ADP of Material Transportations and Construction Work}

This section presents the ADP fossil of material transportations and construction work. The total ADP Fossil from material transportations, and construction and demolition work is $2400 \mathrm{GJ}$, or $0.8 \mathrm{GJ} / \mathrm{m}^{2}$. The results are as follows:

- $\quad$ Total mass (building) $4960 \mathrm{t}$;

- Fossil fuels (construction work) $0.249 \mathrm{GJ} / \mathrm{t}$ (Based on data presented in [49]);

- Fossil fuels (demolition work 0.137 GJ/t (Based on data presented in [49]);

- Fossil fuels (transportation) 0.10 t (Based on VTT LIPASTO traffic emissions [88];

- Fossil fuels (total) $0.49 \mathrm{GJ} / \mathrm{t}$;

- ADP fossil energy (building) 2413 GJ.

\subsection{ADP of the Lifetime Operational Energy Use and Comparison to the ADP of Materials}

This shows the results for the ADP Fossil of the lifetime operational energy use of the case building. The calculation of the used conversion factors is also explained in this section. The case building uses a total of $3050 \mathrm{MWh}$ of heating energy for spaces, $5350 \mathrm{MWh}$ for hot water, and $7650 \mathrm{MWh}$ of electricity over 50 years, in terms of end-use of energy (EUE). Heating and hot water is produced with district heat, whereas electricity is taken from the grid.

In order to relate the end-use of energy to the use non-renewable primary energy resources, primary energy conversion factors (PECFs) are needed. Here, these factors are based on the Finnish data [89] and those are 0.77 for district heating and 1.75 for electricity.

As the assessment period covers a 50-year timespan, these conversion factors will not remain constant due to developments in energy production. Therefore, another conversion factor is needed to translate the non-renewable energy consumption of today to match the expected average over the 
50-year assessment period. The future use of non-renewable primary energy is expected to follow closely the estimated future development of Finnish GHG emissions (data prepared by the Finnish Ministry of Employment and the Economy, and presented, for example, in [28]). The conversion factors used here for translating contemporary PECFs to 50-year averages are 0.8 for district heat and 0.4 for electricity and they are named future conversion factors (FCFs).

The following table (Table 6) shows the ADP Fossil for the case building, in terms of total nonrenewable primary energy use over the 50 -year life cycle.

Table 6. End-use of energy, primary energy conversion factors, future conversion factors, and ADP Fossil for the case building from operational energy use over 50-year life cycle.

\begin{tabular}{cccccc}
\hline $\begin{array}{c}\text { End-use energy } \\
\text { of energy, } \\
\text { purpose of use }\end{array}$ & $\begin{array}{c}\text { End-use } \\
\text { of energy } \\
\text { (EUE) } \mathbf{M W h}\end{array}$ & $\begin{array}{c}\text { End-use } \\
\text { of energy } \\
\text { (EUE) GJ }\end{array}$ & $\begin{array}{c}\text { Primary energy } \\
\text { conversion factor } \\
\text { (PECF) }\end{array}$ & $\begin{array}{c}\text { Future } \\
\text { conversion } \\
\text { factor (FCF) }\end{array}$ & $\begin{array}{c}\text { ADP Fossil/Total non- } \\
\text { renewable primary } \\
\text { energy use, 50a (GJ) }\end{array}$ \\
\hline Heating energy & 3050 & 10,980 & 0.77 & 0.8 & 7063 \\
Hot water & 5350 & 19,260 & 0.77 & 0.8 & 12,389 \\
Electricity & 7650 & 27,540 & 1.75 & 0.4 & 19,278 \\
Total & 16,050 & 57,780 & - & - & 38,730 \\
\hline
\end{tabular}

Figure 1 combines the ADP Fossil values for operational energy use from Table 6, for building materials from Table 2, for soil stabilization from Table 3, and for material-related processes from Section 5.5. The respective ADP Fossil values for the different items are as follows: heating energy $7100 \mathrm{GJ}\left(2.32 \mathrm{GJ} / \mathrm{m}^{2}\right)$, hot water $12,400 \mathrm{GJ}\left(4.05 \mathrm{GJ} / \mathrm{m}^{2}\right)$, electricity $19,300 \mathrm{GJ}\left(6.31 \mathrm{GJ} / \mathrm{m}^{2}\right)$, building materials $15,900 \mathrm{GJ}\left(5.20 \mathrm{GJ} / \mathrm{m}^{2}\right)$, material-related processes $2400 \mathrm{GJ}\left(0.78 \mathrm{GJ} / \mathrm{m}^{2}\right)$, and site construction (soil stabilization) $6400 \mathrm{GJ}\left(2.09 \mathrm{GJ} / \mathrm{m}^{2}\right)$.

Figure 1. Fossil energy consumption (net calorific value) over the life cycle of the building.

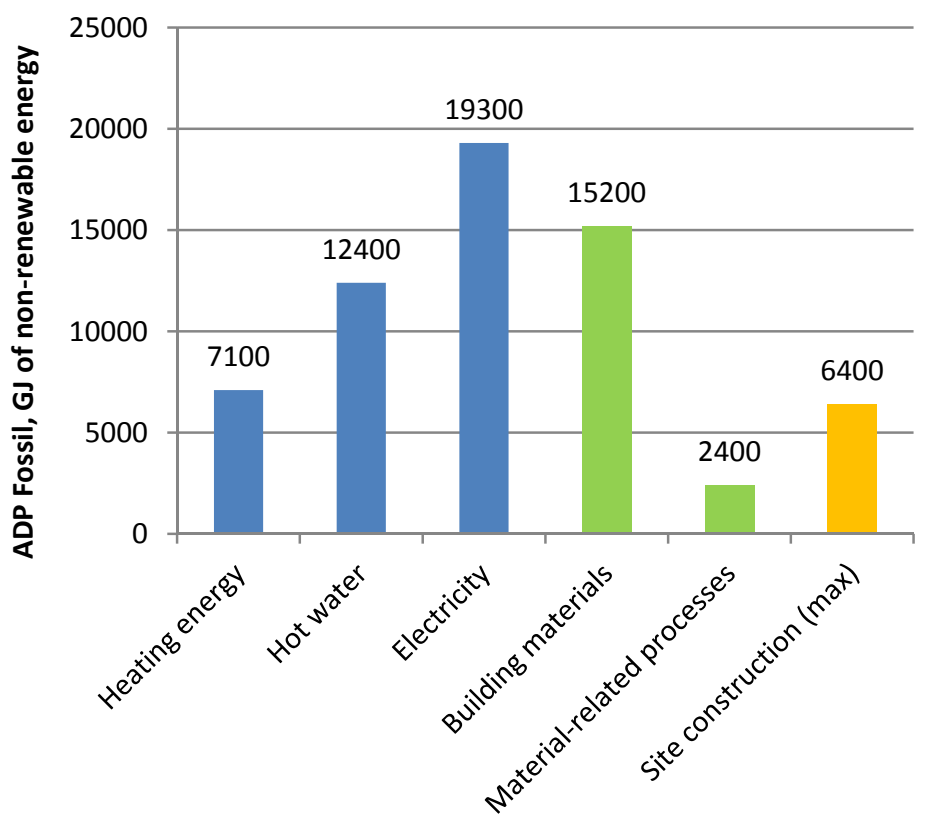


In summary, the APD Fossil due to operational energy totals 38,700 GJ $\left(12.65 \mathrm{GJ} / \mathrm{m}^{2}\right)$ and material-related ADP Fossil is in total $17,600 \mathrm{GJ}\left(5.75 \mathrm{GJ} / \mathrm{m}^{2}\right)$ or $24,000 \mathrm{GJ}\left(7.84 \mathrm{GJ} / \mathrm{m}^{2}\right)$, depending on the stabilization needs. Therefore, the total lifetime ADP Fossil varies from 18.5 to $20.5 \mathrm{GJ} / \mathrm{m}^{2}$. The result shows that the role of material-related non-renewable energy consumption for the case-building is at the level of $30 \%$ to $40 \%$ of lifetime total energy consumption.

\section{Discussion}

The case-study of this research aimed to fill in the gaps in the current knowledge, as identified in the literature review. It looked into the depletion of natural raw materials, through an assessment of lifetime abiotic depletion potential (ADP) of a residential multi-storey case-building with concrete structures, for both ADP elements and ADP fossil, as defined in current guidelines $[24,25,63]$. It should be highlighted that due to the case-study approach, the generalization of the results should be done with caution, especially considering the building type and location.

The material quantities were extracted from the building information model (BIM) of a real world building, so the data accuracy for initial material consumption can be considered high. The material losses, on the other hand, were estimated to be at the level of $5 \%$ of total material consumption. Commonly used values in literature vary from $0 \%$ to $10 \%$ [70]. Also, the lifetime material needs for replacements and refurbishments were assessed through simple estimates on service lives of different building components. An analysis on the impacts of estimation errors show that a change of $25 \%$ in these factors would increase/decrease the material amounts by some $10 \%$ for the case-building.

The case-study used the European reference life cycle database, ELCD [71] to derive the abiotic material inputs and energy requirements for each of the main materials of the building. The LCIs of the database are compiled mainly by process analysis. It can be argued that this method is associated with underestimation of the impacts, as the number of processes and the order of upstream processes are limited [68], and sufficient boundaries may be difficult to cover due to the complexity of upstream processes [69]. For basic building materials, for example, the incompleteness factor, often referred to as truncation error [66] is estimated to be at least $10 \%$ [69], some estimates being as high as $60 \%$ for residential buildings [67].

It should be noted that the data sources for the ELCD-database are drawn on a wider regional level and the energy inputs for the production processes use country-level statistics and national grid-mix information and they are not pure process based analyses. This enhancement of process-based information with IO-based data can be considered to make the profiles of ELCD profiles hybrid analyses in a sense [69].

The ADP characterization factors used for the calculation of ADP elements embody significant uncertainty in them. This research used the CLM database's base reserve figures [72], as recommended in European ILCD handbook [63]. However, the current standards [24,25] do not explicitly state which reserve estimates to use, and some LCAs and EPDs may still be assessed using the ultimate reserve figures, as this has been a past recommendation [64]. The ADP characterization factor for base reserves of copper, for example, is two times bigger than that for the ultimate reserves, for iron 30 times bigger and for aluminium, 23,000 times bigger. This makes it difficult to reliably compare the results of ADP studies between each other. However, the ADP of the case building, 
$1.05 \mathrm{~kg}$ of Antimony equivalents for almost five million kilograms (4960 t) of building materials can be compared to the production of some basic metals from virgin raw materials. The production of $420 \mathrm{~kg}$ of copper, $41,500 \mathrm{~kg}$ of aluminium, or $630,000 \mathrm{~kg}$ of iron from virgin raw materials would produce the same ADP of $1.05 \mathrm{~kg}$ [72]. These comparisons suggest that the result for ADP of the building is of very low level.

Only $0.7 \%$ of the abiotic material inputs of the case building have a characterization factor in the first place, making the ADP elements assessment practically worthless. The basic issue behind this is that such factors cannot be defined for any of the common building materials, such as gypsum, silica sand, construction sand, clays, limestone, and such, due to lack of data on material configurations, reserves, reserve bases and ultimate reserves for these materials [65]. Based on the results of the case-study, the benefits and purpose of calculating ADP elements for buildings is highly questionable in its current form. Methods, which would better account for local scarcity of resources [37] or land or social impacts [38], could fit the purpose better.

The assessment of advanced building systems resulted in ADP elements of $0.12 \mathrm{~kg}$. For solar panels, the figures were 180 and $180,000 \mathrm{~kg}$ of Antimony equivalents. The results of advanced building systems show that such systems may be of relatively high importance, compared to the building itself.

The case-study of this research also assessed the APD Fossil for the materials of the case-building. The uncertainties related to these calculations, concerning the material quantities and the used LCI database are the same, which were discussed previously for ADP elements. As ADP fossil is defined in terms of non-renewable energy, the problem of characterization factors does not have an effect on the results. The assessment results showed that the material-related ADP Fossil totalled from 17,600 GJ $\left(5.75 \mathrm{GJ} / \mathrm{m}^{2}\right)$ to $24,000 \mathrm{GJ}\left(7.84 \mathrm{GJ} / \mathrm{m}^{2}\right)$. Research on similar buildings is limited but, for example, results of two residential buildings with concrete frame and floor area of some $1200 \mathrm{~m}^{2}$ in Sweden, show embodied energy from 4.6 to $5.4 \mathrm{GJ} / \mathrm{m}^{2}$ [90], as summarized in Ramesh et al. [44]. It should be pointed out that the embodied energy figures are not directly comparable to the ADP fossil figures, as the ADP fossil does not include the use of renewable energy.

The ADP fossil due to operational energy totalled to $38,700 \mathrm{GJ}\left(12.65 \mathrm{GJ} / \mathrm{m}^{2}\right)$ in the case-study. The results show that the material-related non-renewable energy consumption of the case building was at the level of $30 \%$ to $40 \%$ of lifetime total non-renewable energy consumption. These results are in line with a GHG assessment of the same building, done in a previous research, showing that material-related GHG emissions accounted for $40 \%$ to $50 \%$ of lifetime total emissions [28]. The comparable result is largely explained by the fact that GHG emissions are mainly due to consumption of fossil energy resources. As discussed above, ADP fossil does not contain renewable energy. In Finland, for example, the share of renewable energy sources in energy production was $27 \%$ in the year 2010 [91].

The operational energy consumption (end-use of energy) was assessed based on standard consumption figures, stated in Finnish regulations. The energy consumption of the case building was $105 \mathrm{kWh} / \mathrm{m}^{2}$. The real consumption figures may vary from this significantly, due to user behavior, as shown in previous research [92]. However, assessment of user behavior was not the focus of this study and this variation was not considered in the assessment. In order to convert the end-use of energy into non-renewable primary energy use, Finnish national-level energy production information was 
used [89] and, in order to take the future development towards low-emission energy production, conversion factors based on [28] were used. Whereas the present-day ratio of non-renewable primary energy to end-use of energy can be thought to be a relatively reliable figure, the future conversion factors depend on political decisions in the future and cannot be predicted accurately. For example, a decrease of $25 \%$ in these factors would impact the results significantly, indicating higher than expected share of renewable energy in the future and lower than expected share of non-renewable energy. For the case-study, such change would decrease the ADP fossil from operational energy use from $12.65 \mathrm{GJ} / \mathrm{m}^{2}$ to $9.5 \mathrm{GJ} / \mathrm{m}^{2}$. This would increase the role of material-related energy consumption from the level of $35 \%$ to $45 \%$ of lifetime totals.

The study was founded on the premise that the importance of material efficiency is based on one or more of the following impacts:

- the depletion of raw materials and its long-term socio-economic impacts;

- land use change due to the extraction of raw materials and its environmental impacts and impacts on the landscape and future recreational use;

- the use of energy in production processes of materials and depletion of non-renewable energy;

- harmful emissions from production processes of materials and their local and/or global environmental impacts;

- material cost impacts due to the limited availability of raw materials or a higher need for energy and/or labor in the different phases of production processes.

This research did a comprehensive literature study to outline and draw conclusions about different aspects of the material efficiency of buildings.

Material efficiency is a complex issue to deal with in steering because there is no widely acknowledged way to make different materials commensurable. The impacts of material efficiency extend to all the aspects of resource efficiency, as shown with Equation (1) of this paper. The demand for new buildings is influenced by their durability, service life and flexibility. The use of lightweight structures impacts the average mass per product, and the yield ratio is affected by material losses on the building site. Finally, the use of secondary materials typically reduces the emissions from production. Due to the comprehensive nature of material efficiency, the focus of policy formulation should not be on its individual components, such as yield rates, average masses per products, and such, but on the impacts caused by material efficiency. Söderholm and Tilton [14] argue similarly, that it is better to avoid policies that directly encourage specific material efficiency options, and that policies should address particular environmental problems and information externalities to enhance material efficiency in instead.

The study was founded on the premise that the importance of material efficiency is based on some of its impacts. The importance of the different impacts (indicated with indicators) can be viewed from the perspective of sustainable development. An indicator can be validated as applicable to sustainable building if it fulfils two minimum requirements: it must be related to a subject of concern for sustainable development, and buildings must have a significant impact on that issue [93].

From the perspective of sustainable development, the greenhouse gas emissions from building sector are an example of an environmental problem, on which material efficiency has a significant 
impact on. Greenhouse gas emissions from building sector are a significant contributor on global warming, and material efficiency has a significant impact on the issue.

The consumption of non-renewable energy resources is near analogous to the greenhouse gas emissions, as the greenhouse gas emissions are mainly the result of consumption of non-renewable fossil energy in production processes of materials. This analogy was also partly illustrated by the results of the case-study.

However, the results on material-related land use showed that the importance of material-efficiency on land-use was practically negligible, as the footprint of the building was significantly more important than the land used for the extraction of non-renewable raw materials.

From the viewpoint of costs, the results showed that the role of materials is only small, some $10 \%$ to $40 \%$ of the construction costs. This means that both savings through improved material efficiency, and additional costs through future price increases in materials, have only a limited impact on total costs.

The construction industry consumes significant amounts of raw materials globally. However, the most common building materials are also common in nature. The results suggest that the most common building materials have no significant impact on depletion natural raw materials globally, although locally this might be important. However, the case might be different for some scarcer resources, which are used in advanced building systems. The case of non-renewable energy resources is different, as discussed previously. The material efficiency has a significant impact on the consumption of non-renewable energy resources.

The impact indicators for material efficiency should be concrete and they should indicate problems, which have global significance. As such, the resource depletion indicators of the current guidelines for buildings do not fully support this. This research suggests that the material efficiency should focus on the significant global impacts of material efficiency, not on the individual factors of it. At the present-day, global warming and greenhouse gas emissions are among the biggest global problems, on which material efficiency has a direct and significant impact on. Therefore, this paper suggests that greenhouse gas emissions could be used as an indicator for material efficiency in building.

\section{Conclusion}

Material efficiency is emphasized as an important aspect of sustainable building, as indicated by the inclusion of the ADP aspect in EN 15804 [24] and EN 15978 [25] and the inclusion of the new basic requirement for sustainable use of resources in the Construction Product Regulation [60]. The roadmap to a resource-efficient Europe [3] addresses buildings as one of the three key sectors. However, further research is still needed to clarify and draw conclusions about the correct indicators and methods to assess the material efficiency of buildings and construction.

This research studied the different aspects of material efficiency: scarcity, land use, and environmental impacts related to the manufacturing of materials.

The preliminary results received with the help of a comprehensive case study (which was aimed at all the materials used for the case building) revealed that basic building materials have only a minor effect on the results when assessed in terms of ADP elements (as recommended by ILCD [63]). Approximately $99 \%$ of building materials have no effect on the ADP value, and, thus, approximately $1 \%$ of the materials (by weight) determine the results. The basic building materials that affect the 
results are the metallic materials used in buildings (steel, aluminium and copper). The result also showed that very minor material flows (in terms of weight), such as lamps and solar panels, may have a significantly bigger effect than any of the basic building materials, including all the metal used. The result raises questions of whether the ADP elements assessment method is appropriate for the assessment of buildings and construction. On the other hand, the ADP fossil fuel calculations were able to capture the material impacts more effectively. When comparing the ADP fossil values from material-related sources with the values from operational energy use, the share of materials accounted for approximately $30 \%$ to $40 \%$ of the lifetime totals.

Despite the relatively low impact on the depletion of abiotic resources, the building materials still have local impacts on the landscape and natural environment. The impacts of the extraction of gravel on ground water may also be substantial on local level. The impact of land use of abiotic materials is small compared with the footprint of the building. The land use of the building itself dominates the results (unless the land used for wood used for heating energy production is taken into account). If the use of wood is taken into account, its impact dominates in terms of land use and but also with regard to biodiversity impacts.

The greenhouse gas emissions from building sector are examples of environmental problems, on which material efficiency has a significant impact on. Greenhouse gas emissions from buildings are affected by all the aspects of material efficiency, and improvements in material efficiency can have significant impacts on the amount of emissions. This paper suggests that greenhouse gas emissions could be used as an indicator for material efficiency in building.

\section{Acknowledgments}

This study was a part of the Sustainability and performance assessment and benchmarking of buildings (SuPerBuildings) project (FP7 EU Project 2010-2012) and the Ownership in sustainable building (OKRA) project (2011-2014) funded by TEKES - the Finnish Funding Agency for technology and Innovation.

\section{Author Contributions}

The article was done in collaboration of the authors. The case study was done by Antti Ruuska, the study of literature was done equally by both authors. The second author, Tarja Häkkinen was the supervisor while the main writing was done by Antti Ruuska.

\section{Conflicts of Interest}

The authors declare no conflict of interest.

\section{References}

1. The Federation of Finnish Technology Industries (Teknologiateollisuus) 2013. Kilpailukykyä ja uutta liiketoimintaa materiaalitehokkuudesta. (In Finnish) Available online: http://www. teknologiateollisuus.fi/file/15592/Materiaalitehokkuusjulkaisu2013.pdf.html (accessed on 13 February 2014). 
2. European Commission. A resource-efficient Europe-Flagship initiative under the Europe 2020 Strategy. COM (2011) 21. Brussels, 26.1.2011. Available online: http://ec.europa.eu/resourceefficient-europe/pdf/resource_efficient_europe_en.pdf (accessed 23 June 2014).

3. European Commission. Roadmap to a Resource Efficient Europe. COM (2011) 571 final. Brussels, 20.9.2011. Available online: http://ec.europa.eu/environment/resource_efficiency/pdf/com2011 571.pdf (accessed 23 June 2014).

4. Berge, B. The Ecology of Building Materials, 2nd ed.; Elsevier: Italy, 2009; p. 427.

5. Azapagic, A. Developing a framework for sustainable development indicators for the mining and minerals industry. J. Clean. Prod. 2004, 12, 639-662.

6. European Commission. Critical raw materials for the EU. Technical Report, June 2010. Available online: http://ec.europa.eu/enterprise/policies/raw-materials/files/docs/report-b_en.pdf (accessed on 21 January 2014).

7. Brent, A.C.; Hietkamp, S. The Impact of Mineral Resource Depletion. Int. J. Life Cycle Assess. 2006, 11, 361-362.

8. Steen, B.A. Abiotic resource depletion. Different perceptions of the problem with mineral deposits. Int. J. Life Cycle Assess. 2006, 1, 49-54.

9. Strauss, K.; Brent, A.; Hietkamp, S. Characterisation and normalisation factors for life cycle impact assessment mined abiotic resources categories in south Africa. The manufacturing of catalytic converter exhaust systems as a case study. Int. J. Life Cycle Assess. 2006, 11, 162-171.

10. Meadows, D.H.; Randers, J.; Meadows, D.L. Limits to Growth. The 30-Year Update; Earthscan: Oxford, UK, 2005; p. 338.

11. Jolliet, O.; Müller-Wenk, R.; Bare, J.; Brent, A.; Goedkoop, M.; Heijnungs, R.; Itsubo, N.; Peña, C.; Pennington, D.; Potting, J.; et al. The LCIA Midpoint-damage Framework of the UNEP/SETAC Life Cycle Initiative. Int. J. Life Cycle Manag. 2004, 9, 394-404.

12. Yellishetty, M.; Ranjith, P.G.; Tharumarajah, A.; Bhosale, S.A. Life cycle assessment in the minerals and metals sector: A critical review of selected issues and challenges. Int. J. Life Cycle Assess. 2009, 14, 257-267.

13. Finnveden, G. The Resource Debate Needs to Continue. Int. J. Life Cycle Assess. 2005, 10, 372-372.

14. Söderholm, P.; Tilton, J.E. Material efficiency: An economic perspective. Resour. Conserv. Recycl. 2012, 61, 75-82.

15. Vieira, M.D.M.; Ponsioen, T.C.; Goedkoop, M.J.; Huijbregts, M.A.J. Surplus cost as a life cycle impact indicator for mineral resource scarcity. Available online: http://www.lc-impact.eu/ userfiles/D_1_4_mineral_and_fossil_resource_use.pdf(accessed on 10 December 2013).

16. Ponsionen, T.C.; Vieira, M.D.M.; Goedkoop, M.J. Surplus cost as a life cycle impact indicator for fossil resource depletion. Available online: http://www.lc-impact.eu/userfiles/D_1_4_mineral_ and_fossil_resource_use.pdf(accessed on 10 December 2013).

17. Rees, W.; Wackernagel, M. Urban ecological footprints: Why cities cannot be sustainable-And why they are a key to sustainability. Environ. Impact Assess. Rev. 1996, 16, 223-248.

18. Haberl, H.; Wackernagel, M.; Krausmann, F.; Erb, K.-H.; Monfreda, C. Ecological footprints and human appropriation of net primary production: A comparison. Land Use Policy 2004, 21, 279-288. 
19. European Environment Agency. Land accounts for Europe 1990-2000, towards integrated land and ecosystem accounting, EEA Report No 11/2006. Available online: http://www.eea.europa.eu /publications/eea_report_2006_11 (accessed 23 June 2014).

20. Eurostat. Economy-wide Material Flow Accounts and Derived Indicators - A Methodological Guide; Office for Official Publications of the European Communities: Luxembourg, Luxembourg, 2001. Available online: http://epp.eurostat.ec.europa.eu/portal/page/portal/environmental_accounts/ documents/3.pdf (accessed 23 June 2014)

21. Van der Voet, E.; van Oers, L.; Moll, S.; Schütz, H.; Bringezu, S.; de Bruyn, S.; Sevenster, M.; Warringa, G. Policy Review on Decoupling: Development of Indicators to Assess Decoupling of Economic Development and Environmental Pressure in the EU-25 and AC-3 Countries; Department Industrial Ecology, Leiden University: Leiden, The Netherlands, 2004.

22. Tukker, A.; Huppes, G.; van Oers, L.; Heijungs, R. Environmentally Extended Input-Output Tables and Models for Europe; Eder, P., Delgado, L., Neuwahl, F., Eds.; EC, JRC, IPTS Technical Report Series, EUR 22194 EN, Seville, Spain, 2006. Available online: http://ftp.jrc.es/EURdoc/eur22194en.pdf (accessed on 23 June 2014).

23. Berger, M.; Finkbeiner, M. Correlation analysis of life cycle impact assessment indicators measuring resource use. Int. J. Life Cycle Assess. 2011, 16, 75-81.

24. EN 15804:2012 Sustainability of construction works - Environmental product declarations - Core rules for the product category of construction products. 2012. Available online: http://standards. cen.eu/dyn/www/f?p=204:110:0::::FSP_PROJECT:40703\&cs=1C696AB3A6B08F09003DC00E 3E3B2DA17 (accessed 23 June 2014).

25. EN 15978:2011. Sustainability of construction works-Assessment of environmental performance of buildings - Calculation method. 2011. Available online: http://standards.cen.eu/dyn/www/f?p $=204: 110: 0:::$ :FSP_PROJECT:31325\&cs=16BA443169318FC086C4652D797E50C47 (accessed 23 June 2014).

26. Stewart, M.; Weidema, B.P. A Consistent Framework for Assessing the Impacts from Resource Use-A focus on resource functionality. Int. J. Life Cycle Assess. 2005, 10, 240-247.

27. Pennington, D.W.; Potting, J.; Finnveden, G.; Lindeijer, E.; Jolliet, O.; Rydberg, T.; Rebitzer, G. Life cycle assessment Part 2: Current impact assessment practice. Environ. Int. 2004, 30, 721-739.

28. Ruuska, A.; Häkkinen, T.; Vares, S.; Korhonen, M.-R.; Myllymaa, T. Environmental Impacts of Building Materials (Rakennusmateriaalien ympäristövaikutukset), Finnish Ministry of Environment, 8/2013 (In Finnish). Available online: http://www.ym.fi/download/noname/\%7B1FAF46B22649-41ED-B3AA-5EA789C9512F\%7D/37571 (accessed on 31 January 2014).

29. Salmi, O.; Haapalehto, T.; Harlin, A.; Häkkinen, T.; Kangas, H.; Mroueh, U.-M.; Qvintus, P. The Development of Material Efficiency in the Finnish Industries; Technical Report for The Ministry of employment and the economy (In Finnish): Helsinki, Finland, 2013; p. 46.

30. Allwood, J.M.; Ashby, M.F.; Gutowski, T.G.; Worrell, E. Material efficiency: A white paper. Resour. Conserv. Recycl. 2011, 55, 362-381.

31. Prior, T.; Giurco, D.; Mudd, D.; Mason, L.; Behrich, J. Resource depletion, peak minerals and the implications for sustainable resource management. Glob. Environ. Chang. 2012, 22, 577-587. 
32. Wouters, H.; Bol, D. Material Scarcity; Materials Innovation Institute: Delft, The Netherlands, 2009.

33. De Almeida, P.; Silva, P.D. The peak of oil production-Timings and market recognition. Energy Policy 2009, 37, 1267-1276.

34. European Commission. The raw materials initiative-Meeting our critical needs for growth and jobs in Europe. COM 699. Brussels, 4.11.2008. Available online: http://ec.europa.eu/enterprise/ sectors/metals-minerals/files/com699_en.pdf (accessed 23 June 2014).

35. Ahmed, M.S.; Vidyadhara, H.S. Experimental study on strength behaviour of recycled aggregate concrete. Int. J. Eng. Res. Technol. 2013, 2, 76-82.

36. Lohani, T.K.; Padhi, M.; Dash, K.P.; Jena, S. Optimum utilization of quarry dust as partial replacement of sand in concrete. Int. J. Appl. Sci. Eng. Res. 2012, 1, 391-404.

37. Habert, G.; Bouzidi, Y.; Chen, C.; Jullien, A. Development of a depletion indicator for natural resources used in concrete. Resour. Conserv. Recycl. 2010, 54, 364-376.

38. Yellishetty, M.; Mudd, G.M.; Ranjith, P.G. The steel industry, abiotic resource depletion and life cycle assessment: A real or perceived issue? J. Clean. Prod. 2011, 19, 78-90.

39. U.S. Department of Energy, Critical Materials Strategy Summary, 2011. Available online: http://energy.gov/sites/prod/files/DOE_CMS2011_FINAL_Full.pdf (accessed on 7 January 2014).

40. Gleich, B.; Achzet, B.; Mayer, H.; Rathgeber, A. An empirical approach to determine specific weights of driving factors for the price of commodities - A contribution to the measurement of the economic scarcity of minerals and metals. Resour. Policy 2013, 38, 350-362.

41. Sartori, I.; Hestnes, A.G. Energy use in the life cycle of conventional and low-energy buildings: A review article. Energy Build. 2007, 39, 249-257.

42. Hernandez, P.; Kenny, P. Development of a methodology for life cycle building energy ratings. Energy Policy 2011, 39, 2779-3788.

43. Stephan, A.; Crawford, R.H.; de Myttenaere, K. Towards a more holistic approach to reducing the energy demand of dwellings. In Proceedings of the 2011 International Conference on Green Buildings and Sustainable Cities, Procedia Engineering, Bologna, Italy, 15-16 September, 2011; pp. 1033-1041.

44. Ramesh, T.; Prakash, R.; Shukla, K.K. Life cycle energy analysis of buildings: An overview. Energy Build. 2010, 42, 1592-1600.

45. Yung, P.; Lam, K.C.; Yu, C. An audit of life cycle energy analyses of buildings. Habitat Int. 2013, 39, 43-54.

46. Aktas, C.B.; Bilec, M.M. Impact of lifetime on US residential building LCA results. Int. J. Life Cycle Assess. 2011, 17, 337-349.

47. Rauf, A.; Crawford, R.H. The relationship between material service life and the life cycle energy of contemporary residential buildings in Australia. Archit. Sci. Rev. 2013, 56, 252-261.

48. Stephan, A.; Crawford, R.H.; de Myttenaere, K. Multi-scale life cycle energy analysis of a low-density suburban neighbourhood in Melbourne, Australia. Build. Environ. 2013, 68, 35-49.

49. Fuller, R.J.; Crawford, R.H. Impact of past and future residential housing development patterns on energy demand and related emissions. J. Hous. Build. Environ. 2011, 26, 165-183.

50. Säynäjoki, A.; Heinonen, J.; Junnila, S. A scenario analysis of the life cycle greenhouse gas emissions of a new residential area. Environ. Res. Lett. 2012, 7, 034037:1-034037:10. 
51. Milà i Canals, L.; Bauer, C.; Depestele, J.; Dubreuil, A.; Freiermuth Knuchel, R.; Gaillard, G.; Michelsen, O.; Müller-Wenk, R.; Rydgren, B. Key elements in a framework for land use impact assessment within LCA. Int. J. Cycle Assess. 2007, 12, 5-15.

52. Marshall, E.; Shortle, J. Urban Development Impacts on Ecosystems. In Land Use Problems and Conflicts: Causes Consequences and Solutions; Goetz, S., Shortle, J., Bergstrom, J., Eds.; Routledge Publishing: New York, NY, USA, 2005.

53. Scalenghe, R.; Marsan, F.A. The anthropogenic sealing of soils in urban areas. Landsc. Urban Plan. 2009, 90, 1-10.

54. Wheater, H.; Evans, E. Land use, water management and future flood risk. Land Use Policy 2009, 26, 251-264.

55. Häkkinen, T.; Helin, T.; Antuña, C.; Supper, S.; Schiopu, N.; Nibel, S. Land Use as an Aspect of Sustainable Building. Int. J. Sustain. Land Use Urban Plan. 2013, 1, 21-41.

56. Finnish Ministry of Environment. Sustainable use of soil materials. Guidelines of the Ministry of environment. Available online: http:/www.ymparisto.fi/download.asp?contentid=101195\&lan=fi (accessed on 30 August 2013).

57. Goodrum, P.M.; Zhai, D.; Yasin, M. Relationship between Changes in Material Technology and Construction Productivity. J. Constr. Eng. Manag. 2009, 135, 278-287.

58. European Parliament, European Council, Directive 2002/91/EC of the European Parliament and of the Council of 16 December 2002 on the energy performance of buildings, 2002. Available online: http://eur-lex.europa.eu/legal-content/EN/TXT/PDF/?uri=CELEX:32002L0091\&from=EN (accessed 23 June 2014).

59. European Parliament, European Council, Directive 2010/31/EU of the European Parliament and of the Council of 19 May 2010 on the energy performance of buildings, 2010. Available online: http://eur-lex.europa.eu/LexUriServ/LexUriServ.do?uri=OJ:L:2010:153:0013:0035:EN:PDF (accessed 23 June 2014).

60. Cansino, J.M.; Pablo-Romero, M.P.; Román, R.; Yñiguez, R. Promoting renewable energy sources for heating and cooling in EU-27 countries. Assessment of the sustainable building steering mechanisms in selected EU member states. Energy Policy 2011, 39, 3803-3812.

61. Tuominen, P.; Klobut, K.; Tolman, A.; Adjei, A.; de Best-Waldhober, M. Energy savings potential in buildings and overcoming market barriers in member states of the European Union. Energy Build. 2012, 51, 48-55.

62. European Union. The Construction Products Regulation (EU) No 305/2011 (CPR). 2011. Available online: http://eur-lex.europa.eu/LexUriServ/LexUriServ.do?uri=OJ:L:2011:088:0005: 0043:EN:PDF (accessed 23 June 2014).

63. European Commission Joint Research Centre (JRC). ILCD Handbook: Recommendations for Life Cycle Impact Assessment in the European Context; Publication Office of the European Union: Luxembourg, Luxembourg, 2011. Available online: http://publications.jrc.ec.europa.eu/ repository/bitstream/111111111/26229/1/jrc61049_ilcd\%20handbook\%20final.pdf (accessed on 4 February 2014). 
64. Guinée, J.B.; Gorrée, M.; Heijungs, R.; Huppes, G.; Kleijn, R.; Koning, A.; de Oers, L.; van Wegener Sleeswijk, A.; Suh, S.; de Haes, H.A.; et al. Handbook on Life Cycle Assessment. Operational Guide to the ISO Standards. I: LCA in Perspective. IIa: Guide. IIb: Operational annex. III: Scientific background; Kluwer Academic Publishers: Dordrecht, The Netherlands, 2002; p. 692.

65. Van Oers, L.; de Koning, A.; Guinée, J.B.; Huppes, G. Abiotic Resource Depletion in LCA, Improving Characterization Factors for Abiotic Resource Depletion as Recommended in the New Dutch LCA Handbook; Road and hydraulic engineering institute: Amsterdam, The Netherlands, 2002.

66. EN ISO 14040:2006. Environmental Management. Life Cycle Assessment. Principles and Framework; The International Organization for standardization: London, UK, 2006.

67. Crawford, R.H. Validation of a hybrid life-cycle inventory analysis method. J. Environ. Manag. 2008, 88, 496-506.

68. Suh, S.; Lenzen, M.; Treloar, G.J.; Hondo, H.; Horvath, A.; Huppes, G.; Jolliet, O.; Klann, U.; Krewitt, W.; Moriguchi, Y.; Munksgaard, J.; Norris, G. Critical review: System Boundary Selection in Life-Cycle Inventories Using Hybrid Approaches. Environ. Sci. Technol. 2004, 38, $657-664$.

69. Treloar, G.J. Extracting Embodied Energy Paths from Input-Output Tables: Towards an Input-Output-based Hybrid Energy Analysis Method. Econ. Syst. Res. 1997, 9, 375-391.

70. Dixit, M.K.; Culp, C.H.; Férnandez-Solís, J.L. System boundary for embodied energy in buildings: A conceptual model for definition. Renew. Sustain. Energy Rev. 2013, 21, 153-164.

71. European Commission Joint Research Centre (JRC). European reference Life Cycle Database, ELCD, European Platform on Life Cycle Assessment. Available online: http://eplca.jrc.ec.europa. eu/?page_id=126 (accessed on 23 June 2014).

72. University of Leiden, CML-IA Characterisation Factors, CML, 2013. Available online: http://www.leidenuniv.nl/cml/ssp/databases/cmlia/cmlia.zip (accessed on 26 January 2014).

73. Soules, T.F.; Whitman, P.K.; Chirayath, D.R. Fluorescent lamp with phosphor coating of multiple layers, European Patent Specification, EP 0807958B1, European Patent Office, 30 October 2012.

74. U.S. Environmental Protection Agency. Office of Solid Waste, Mercury Emissions from Disposal of Fluorescent Lamps; Office of Solid Waste U.S. Environmental Protection Agency: Washington, DC, USA, 30 June 1997.

75. European aluminium association (EAA). Aluminium extrusion profile, LCI data set, European reference Life Cycle Database, ELCD, 2013. Permanent dataset URI. Available online: http://lca. jrc.ec.europa.eu/lcainfohub/datasets/elcd/processes/09215eb0-5fc9-11dd-ad8b-0800200c9a66.xml (accessed on 23 June 2014).

76. PE International, Pre-cast concrete, LCI data set. European reference Life Cycle Database, ELCD, 2013. Permanent dataset URI. Available online: http://lca.jrc.ec.europa.eu/lcainfohub/datasets/ elcd/processes/898618b0-3306-11dd-bd11-0800200c9a66.xml (accessed on 23 June 2014).

77. European Copper Institute, Copper tube, LCI data set. European reference Life Cycle Database, ELCD, 2013. Permanent dataset URI. Available online: http://lca.jrc.ec.europa.eu/lcainfohub/ datasets/elcd/contacts/42a11490-573c-11dd-ae16-0800200c9a66.xml (accessed on 23 June 2014). 
78. PE International, Polypropylene fibres (PP), LCI data set. European reference Life Cycle Database, ELCD, 2013. Permanent dataset URI. Available online: http://lca.jrc.ec.europa.eu/ lcainfohub/datasets/elcd/processes/db00901b-338f-11dd-bd11-0800200c9a66.xml (accessed on 23 June 2014).

79. PE International, Gravel 2/32, LCI data set. European reference Life Cycle Database, ELCD, 2013. Permanent dataset URI. Available online: http://lca.jrc.ec.europa.eu/lcainfohub/datasets/ elcd/processes/898618b2-3306-11dd-bd11-0800200c9a66.xml (accessed on 23 June 2014).

80. Eurogypsum, Gypsum Plasterboard, LCI data set. European reference Life Cycle Database, ELCD, 2013. Available online: http://lca.jrc.ec.europa.eu/lcainfohub/datasets/elcd/processes/ cc39e70e-4a40-42b6-89e3-7305f0b95dc4.xml (accessed on 23 June 2014).

81. Steel sections, LCI data set. Worldsteel, European reference Life Cycle Database, ELCD, 2013. Permanent dataset URI. Available online: http://elcd.jrc.ec.europa.eu/ELCD3/resource/processes /09d61948-238a-40e7-8e1f-afdc0c98f902?format=html\&version=03.00.000 (accessed on 23 June 2014).

82. PE-International, Pine wood, European reference Life Cycle Database, ELCD, 2013. Permanent dataset URI. Available online: http://ca.jrc.ec.europa.eu/lcainfohub/datasets/elcd/processes/ 621e64d0-f471-4023-9ebc-a52cd8ee573f.xml (accessed on 23 June 2014).

83. PE-International, Particle board, European reference Life Cycle Database, ELCD, 2013. Permanent dataset URI. Available online: http://lca.jrc.ec.europa.eu/lcainfohub/datasets/elcd/ processes/bd7fdac9-40d5-4613-9374-6969803269d9.xml (accessed on 23 June 2014).

84. Cembureau, Portland cement, European reference Life Cycle Database, ELCD, 2013. Permanent dataset URI. Available online: http://eplca.jrc.ec.europa.eu/ELCD3/resource/processes/600573dddfa5-44e5-b458-8727e793ffd7.xml (accessed on 23 June 2014).

85. European Lime Association, Quicklime, European reference Life Cycle Database, ELCD, 2013. Permanent dataset URI. Available online: http://eplca.jrc.ec.europa.eu/ELCD3/resource/sources/ 7983f4c6-a355-4250-aaa8-5780a72cc1df.xml (accessed on 23 June 2014).

86. European Commission Joint Research Centre (JRC). Characterisation Factors of the ILCD, Recommended Life Cycle Impact Assessment Methods, Database and Supporting Information, JRC Technical Notes; European Union, Publications office of the European Union: Luxembourg, Luxembourg, 2012.

87. Bio Intelligence Service. Study on Photovoltaic Panels Supplementing the Impact Sssessment for a Recast of the WEEE Directive; Final report to European Commission DG ENV, 14 April 2011. Available online: http://ec.europa.eu/environment/waste/weee/pdf/Study\%20on\%20PVs\%20 Bio\%20final.pdf (accessed on 23 June 2014).

88. LIPASTO - A calculation system for traffic exhaust emissions and energy consumption in Finland, VTT Technical Research Centre of Finland. Available online: http://lipasto.vtt.fi/indexe.htm (accessed on 21 January 2014).

89. Keto, M. Energy Factors, General Principles and Factors for Realized Production of Electricity and District Heating; Technical Report for The Ministry of Environment, Aalto University, Espoo, Finland, November, 2010.

90. Adalberth, K.; Almgren, A.; Holleris, P.E. Life-Cycle assessment of four multi-family buildings. Int. J. Low Energy Sustain. Build. 2001, 2, 1-21. 
91. Statistics Finland, Energy Statistics Year book 2011. Available online: http://www.stat.fi/tup/ julkaisut/tiedostot/julkaisuluettelo/yene_enev_201100_2012_6164_net.pdf (accessed on 23 June 2014).

92. Blom, I.; Itard, L.; Meijer, A. Environmental impact of building-related and user-related energy consumption in dwellings. Build. Environ. 2011, 46, 1657-1669.

93. Häkkinen, T. Sustainable Refurbishment of Exterior Walls and Building Facades; VTT: Espoo, Finland, 2012. Available online: http://www.vtt.fi/inf/pdf/technology/2012/T30.pdf (accessed on 23 June 2014).

(C) 2014 by the authors; licensee MDPI, Basel, Switzerland. This article is an open access article distributed under the terms and conditions of the Creative Commons Attribution license (http://creativecommons.org/licenses/by/3.0/). 